INTERACTION: Jurnal Pendidikan Bahasa; Vol. 7, No. 1; Mei 2020

ISSN: 2406-9558; E-ISSN: 2406-9566

\title{
The Students' Perceptions on Teacher "Performances" in Teaching English
}

\author{
Agus Setiawan \\ setiawan.agus513@gmail.com \\ Universitas Pendidikan Muhammadiyah Sorong
}

\begin{abstract}
This study was conducted to find out how the students' perceptions on English teachers. The problem focuses on students' perceptions of the teacher's learning methods while learning the learning takes place, and an effective learning process with student learning outcomes gained. In this study the authors take respondents to get data that is as much as 4 respondents, where the one respondent is an English teacher and 3 other respondents are students. Researchers conducted interviews on each respondent. In this case, the teacher to know the methods used in the learning process and the students to know how performance teacher in the learning process. The method used in this research is descriptive design. This study reveals that teachers' performance in English learning is good, where teachers can apply motivation of students learning, learning model, classroom management, use of facilities, and student experience well. And for the learning method, the teacher does not use special methods in the learning process, but the teacher learning model is applied more to adaptation to the material taught to students. Nevertheless, the teacher will improve the methods in learning and innovate for the success of the learning process.
\end{abstract}

Keywords: Students’ Perception, Teacher Performances

\section{INTRODUCTION}

Education is a conscious and well-planned effort to create an atmosphere of learning process that will make learners actively develop their potential to have spiritual power, self-control, personality, intelligence, noble character, skills, society, nation and state. Education includes the teaching of special skills, as well as something that can't be seen but more deeply that is the giving of knowledge, judgment and wisdom. One of the main foundations of education is to teach culture through generations.

As part of society, education has dual functions as social and individual function. The social function helps individual to become more active in a society by providing the past and present collective experience. Meanwhile, the individual function enables a more satisfying and more productive life of an individual by preparing he/she for the future (new experience). This function can be done formally as it happens in various educational institutions, as well as informally through various contacts with media information such as books, newspapers, magazines, television, radio, and so on. 
Moreover, education is very important for our life because an advanced education can prosper the nation, especially for English education. English is one of the important aspects that should be thought to students, ranging from elementary to college level. English lesson is one of the most important subjects in formal and non-formal education environment because it will be tested in the National Exam. Besides, English is the world wile language used by people around the world.

In the world of learning, especially English, it certainly cannot be separated from method. The method will help teacher to teach better, as systematically, focus on the target language and facilitate the teaching and learning process. The teacher should have skills and knowledge on how to use the method appropriately in order to support students' needs. Besides, student and teacher are the important elements of the teaching and learning process and they cannot be separated. Based on the above background, the researcher is interested on discovering students' perceptions toward the teacher's performance in teaching English, and about the learning model that is used by the teacher. So, the researcher will try to dig as much as information from students about their teacher's performance.

\section{LITERATURE REVIEW}

\section{Previous Study}

The first of related study is Student's Perception of their Teacher Teaching Style's. The purpose of this study is to describe how the students' perception of their teacher teaching style's in math learning. This is qualitative research. The samples in this research are 66 students from class X and class XI which are randomly selected from 600 students of class $\mathrm{X}$ and class XI. The data collection used questionnaires about how students' perception of their teachers teaching style's. The results obtained the state that the mathematics learning model that has been taught and the general student learning experience is still teacher-centered.

The second of related study is Teachers' Perceptions of Academic Performance and Student Engagement among Ninth-Grade Students. The purpose of this qualitative single case study was to explore teachers' perceptions of the prospective causes of poor academic performance of ninth-grade students, with particular attention to cognitive, behavioral, and emotional barriers to student engagement. Self-determination theory provided the interpretative framework for this study. Data were collected through semi structured interviews with 10 ninth-grade teachers, observation of teachers' classrooms, and review of archival documents. Results of 6-phase thematic analysis indicated 8 themes: (a) no or little student engagement, (b) lack of support, (c) lack of basic skills, (d) lack of interest in school, (e) different levels and styles of learning, (f) mind-set in relation to performance, $(\mathrm{g})$ disciplinary issues, and $(\mathrm{h})$ belongingness in the classroom. Results confirmed the importance of students receiving support from 
parents and teachers in developing psycho-social skills to cope with the rigors of high school life. Findings may be used to update teacher training courses to emphasize promoting students' autonomy, competence, and relatedness.

The last of related study is Students' Perception of Teachers' Factors in the Teaching and Learning of English Language in Nigerian Secondary Schools. This paper investigates students' perception of teachers' factors (teachers' attitude, method of teaching and classroom management) in the teaching and learning of English Language in secondary schools in Nigeria. The study is a descriptive research design of the survey method. Two hundred (200) students were randomly selected from 5 secondary schools for the study while only 192 representing $96 \%$ who responded correctly to the instrument were used for the study. Three research questions and three hypotheses were generated. A self- constructed questionnaire titled "Students Perception of Teachers Attitude, Method of Teaching and Classroom Management Scale" (SPTAMTCMS) was used to collect data for the study. Frequency counts, percentages and chi-square statistics were used to analyze the data collected. All hypotheses were tested at 0.05 level of significance. The findings revealed that there was a significant relationship between teachers' attitude, method of teaching and classroom management to the teaching and learning of English Language as perceived by students. This implies that expected performance of students in English Language is based on the teachers' attitude, method of teaching the subject and classroom management.

\section{Perception}

Perception is a process preceded by the sensing process. Sensing is the process of receiving the stimulus by the individual through the sense device called the sensing process. The sensing process will take place at any time, when the individual receives the stimulus through the sensory apparatus, through the eyes as the sighting tool, the nose as a tool of the tongue as a tasting device, the skin on the palm of the hand as a tactile device, all of which are the sense devices used to receive stimuli from outside the individual. Something perceived by someone with another person may differ in its meaning. This is because what is around is captured by the five senses is not directly interpreted with reality. That sense is in the perceived person, the object being perceived and the circumference situation. Based on the perception or giving meaning of what is captured by the five senses that someone is doing activities or perform certain attitudes.

\section{Learning Model Functions}

An appropriate learning model functions can encourage the growth of students' sense of fun toward the lessons, foster and increase motivation in doing the tasks, making it easy for students' to understand the lessons so as to enable students to achieve better learning outcomes. Each model requires a slightly different management system and 
learning environment. Cooperative learning model is a model of learning that prioritizes the existence of groups. The purpose of cooperative learning model is the result of increasing student academic learning and students can receive various diversity from their friends, as well as the development of social skills. Cooperative Learning has several types including: Type Jigsaw (Expert Team), Group Investigation Type, Type of STAD (Student Team Achievement Division), and Think Pair Share Type (TPS).

Problem-based teaching is developed to help students develop thinking skills, problem solving and intellectual skills; learning various roles of adults through their involvement in real experiences or stimulation and others: realistically according to human life, concepts according to the needs of students, fostering the nature of student inquiry, concept retention becomes strong, fosters problem-solving skills. Contextual Teaching and Learning is a learning concept that helps teachers connect between materials taught to the real-world situations of students and encourages students to make connections between their knowledge and application in their lives as family members and the community.

\section{The Learning Factors Process}

\section{Students' Activity}

Artha (1991: 62) states that activity is a very important principle in the interaction of teaching and learning. He also stated that during the teaching-learning process, students do not just listen to a number of theories passively, but students must be actively and actively involved in all learning activities (ie listening, writing, discussion, practice, etc.). Student activities during learning activities according to Pramono (1997: 226) is in the form of questions, problem formulation, work tasks, and exercises.

\section{The ability of Teachers to Manage the Learning Process}

Hudojo (1988: 5) states that the mastery of the material and the way of delivery is an indispensable condition for mathematics teachers. A mathematics teacher who does not master the math material taught, is not likely to teach math well. Similarly, a teacher who does not master the various ways of delivery can cause learners difficulties in understanding mathematics. If any of these things happen, then the process of learning mathematics is not effective.

According to Ali (1987: 7) that the requirements teachers need to possess include: a) mastery of the material, b) the ability to apply psychological principles, c) the ability to organize teaching learning processes, and d) the ability to adapt to various situations. Then Soedjadi (1994: 4 - 5) states that the important key mathematicians must know is 
to be more creative in the learning done, although in teaching the same material and more creative in planning the lesson.

Based on the above opinion, the ability of teachers during the implementation of learning is one requirement that must be owned by a teacher. According to Abdurrahman (2002), things that need to be considered about the ability of teachers in managing learning include: (a) Introduction (explaining the material to be discussed, motivating / arousing student interest, providing guidance before students do LKS), (b) Core activities (communicating learning objectives, problem-solving, guiding students to understanding problems, guiding students to develop activities / data, guiding students to compile data, guiding students to add data, guiding students to find concepts / principles, guiding students to apply concepts) (c) relevant tasks), (d). Time management, (e) Classroom atmosphere (student enthusiasm and teacher enthusiasm).

\section{The Teaching Strategy Factors}

Winataputra, et al. (1992), suggests that the learning strategy is the strategy or the overall activity undertaken by the teacher to create a learning atmosphere conducive to the achievement of learning objectives. Furthermore, it is said that in the learning of English should be chosen learning strategies that can involve students actively. The activity of the students is not only in the skills to do the problem as an application of mathematical concepts that have been studied, but need to be more concerned with understanding the process of concept formation. Then in the book Basic Competency \& Learning Outcomes Mathematics subjects SMP / MTs (Depdiknas, 2001: 14-19), mentioned that the strategy of learning mathematics should be done alone students who understand and construct a concept or knowledge under the guidance of teachers. So, the strategy here is the strategy or the overall activity undertaken by the teacher to create an atmosphere of learning that the students themselves understand and construct a concept or knowledge under the guidance of teachers. Implementation of learning strategies as mentioned above, one of them is by applying guided discovery learning.

\section{Learning tools}

The appropriate English learning tool is very important in the effort to achieve the purpose of learning English. In addition, learning tools can make it easy for students to learn. Slavin (Nur, 1998) suggests that for learning to be done well, students need to be given activities that contain questions or goals that are planned to be done. In relation to this research, a set of instructional tools intended is the Learning Plan (RP), Student Book, Student Activity Sheet (LKS), and the learning result test (THB). The four factors mentioned above, is a very influential factor on the learning process and the results. One of the things to note is that, when a teacher has chosen the appropriate lesson to teach a material, then a suitable tool is needed for the chosen learning. With the availability of appropriate learning tools facilitate teachers in implementing the 
learning so expected to obtain good results. Likewise, to implement the learning of materials with guided discovery required the appropriate device.

\section{METHOD}

\section{Design and Sample}

The researcher used descriptive design to conduct the research because it is focused on a certain phenomenon in the school environment. The researcher used descriptive design because it is appropriate with the study which deals with students' perceptions. According to Nazir (1988: 63) in the Sample Book of Research Method, descriptive method is a method in researching human status, objects, conditions defined, or meaningful influence in the present. The subject of this research are teacher and students in SMK Muhammadiyah 1 Aimas, grade XI. The researcher takes 3 until 5 students and 1 teacher as the respondents. Purposive sampling was used in selecting the respondents. The researcher used purposive sampling because the concept is used in qualitative research (Creswell, 2007). Besides, the number of the participants is undetermined as long as the data gathered has answered the research question, so the small number of participants is adequate (Cresswell, 2012). This means that the researcher selects individuals and sites for the study because they can purposefully inform an understanding of the research problem and "convenience cases, which represent sites or individuals from which researcher can access and easily collect data".

\section{Instrument and Procedure}

In collecting the data, the researcher follows the two stages of descriptive design which is proposed by Sugiyono (2005:21). The first stage is observe the students. In this case, the researcher observes the class condition and teaching and learning process. The use of observation is not only to measure the attitudes of the respondents, but also it can be used to record various phenomena that occur at that time. The observation is suitable for this research that aims to study about human behavior, work processes, and natural phenomena. The second stage is interviewing the student and teacher. The interview aims to discover students' perspectives on teacher's performance in teaching English and to know what kind of learning model used by the teacher. The researcher uses semistructured interview to get important points from the respondents. The process of collecting data is to recruit participants in advance by conducting interviews and observations. In addition, face-to-face interviews for each participant are not done once. It depends on the participant's time and desire. Interviews were conducted using the language so that researchers get the desired data more accurately. 
INTERACTION: Jurnal Pendidikan Bahasa; Vol. 7, No. 1; Mei 2020

ISSN: 2406-9558; E-ISSN: 2406-9566

\section{Data Analysis}

For data analysis, the demographic data were analyzed descriptively in which every participant's information was described. Then, the interview data were transcribed and analyzed line in order to find regularities and emerging themes and subthemes among the data. Data analysis in qualitative research is often done concurrently or simultaneously with data collection. Nevertheless, Ary (2010: 283) states that the data analysis of the study can be broken down into four stages such as coding, data reduction, data display, and drawing conclusion or interpretation. Once all the interviews are coded and analyzed, the researcher starts to identify how the themes and sub-themes help the researcher to explain the research questions. During this process, the researcher also removed or reduced overlapping and repetitive data (Mukminin, Ali, and Ashari, 2015).

\section{RESULT AND DISCUSSION}

The researcher describes the results of interviews in the form of descriptive text. The researcher asked the first respondent about his/her perceptions on teacher 'performances in the class, which include: motivation, learning model, classroom management, the use of facilities, and assessment.

\section{Motivation}

Motivation is a complex feeling. According to Mc. Donald, cited in Oemar Hamalik (2003: 158) motivation is a change in energy in a person characterized by the emergence of feelings and reactions to achieve goals. Based on the interview, the English teachers at SMK Muhammadiyah 1 Aimas stated that he/she gives motivations to his/her students in the teaching and learning process. The teacher motivates his/her students in order to increase students' enthusiasm toward the learning process. Before starting the lesson, the teacher explains the goals to be achieved from the lesson, so that students will be able to capture and digest well the results of the learning. The tteacher also often tell students about a person's willingness and determination to accomplish great things, and thus it will motivate and icrease students' spirit in learning English.

Besides, based on the observation, the researcher found that the learning process is done with fun (fun learning). When the learning atmosphere is good and the students are feeling happy then the subject matter given will be more easily to be understood by students, the learning activities will become more interesting and not boring. Nevertheless, even teacher always give motivation to the students, but not all students can improve their learning motivation. It happens because every students has different attitude and character, so the process will not be the same. 
INTERACTION: Jurnal Pendidikan Bahasa; Vol. 7, No. 1; Mei 2020

ISSN: 2406-9558; E-ISSN: 2406-9566

\section{Learning Model}

Regarding teacher's learning model, the researcher found that the learning model that is done by the English teacher is quite fun. Based on students' perceptions, the researcher found that there are many kinds of learning method used by the teacher. Some respondents (students) answer:

"The teachers often use games in the middle of lesson, or singing a song together by using English-speaking lyrics. So, we do not get bored in the classroom. "

"The teachers are innovative because they not only give students tasks to do in the classroom, but students are occasionally invited to public places such as airport or tourist places to meet with foreign tourists, so that students can directly interact in English."

Then, based on teacher's perseptions toward the use of learning model in teaching English, the researcher found that teacher applies some learning method in the classroom.

"I always apply the learning model so that the learning process is more effective and all the students are active so it is expected to reach the desired level of competency. While the model of learning that I apply to students depends on the subject matter that I provide. For example, the material I teach about drama, then I apply the model of learning that is the nature of the demonstrators or dramas. "

Based on the data above, it can be concluded that the learning model is a strategy used by teachers to improve students' learning motivation, attitude among students, critical thinking, social skills, and achievement of optimal learning outcomes (Isjoni, 2009: 8). Referring to this, the development of learning model continues to change from a traditional model to a modern model. On the observation, the researcher found that teacher apply cooperative learning model. It is a learning strategy with students as members of small groups with different levels of ability (Isjoni, 2009: 14). Further, it says that cooperative learning is a learning method in which students learn and work in small groups collaboratively within $4-6$ members with heterogeneous group structure (Slavin, 1985 as cited in Isjoni, 2010: 12).

\section{Classroom Management}

According to the respondents, classroom management conducted by English teachers in SMK Muhammadiyah 1 Aimas is about discipline. One respondent (student) answer: 
"Teachers are always disciplined in terms of time in the implementation of the learning process, student discipline is also applied in terms of neatness of students and also in student learning tasks".

Then, on the observation, the researcher found that teachers are trying to create and maintain the classroom atmosphere in order the learning process can run properly and effectively. The approach is also done by teachers to develop the desired behavior of learners by reducing undesirable behavior. Teachers also develop good interpersonal relationships and a positive class socio-emotional climate. According Arikunto (1988) in the book Classroom Management and Students, he said that classroom management is an effort made by teachers to help them in creating optimal learning conditions. He argues that the goal of classroom management that every child in the class can learn in an orderly manner so that the teaching objectives can be achieved effectively and efficiently. Reinforced by another expert' opinion, Djamarah and Zain in a book entitled "Teachers and Children in Educational Interaction" (Jakarta: Rineka Cipta, 2006), they mentioned that classroom management is an effort to utilize the potential of existing class as optimal as possible to support the process of interaction educative learning objectives.

\section{The Use Facility}

One aspect that should be concerned by every educational executive is about the facilityies. Educational facilities generally include all facilities that support the educational process, such as: bbuilding, classroom, educational tools or media, tables, chairs, and so on. As each subject matter has different character with another, so, it also requires different learning suggestions. In conducting the learning, a teacher needs tools that can support his/her performance so that the learning can run interestingly and succesfully. With the support of adequate learning facilities, teachers not only can deliver the material orally, but they also can write and demonstratee in accordance with the infrastructure facilities that have been prepared.

From the interview, a student answers that teachers often display English video conversation using projector and tape recorder. And based on the observation, the researcher found that SMK Muhammadiyah 1 Aimas school have adequate facilities bbecause the location of the school is not far from the city. However, the teacher said on the interview that there are still some facilities that are not available in the school, such as language laboratoryy, the lack of English language textbooks, and the projector that is not available in every class. Whereas, the facilities is used to support the learning activities. In addition, the ability of teachers in organizing learning activities, the support from such learning tools is very important in helping teachers. The more 
complete and adequate learning tools owned by a school the more it will facilitate teachers in carrying out their duties as an education personnel.

\section{Assessment}

The assessment of education is an assessment of students' progress and the progress regarding to the mastery of lesson material presented to them and the values contained in the curriculum (Harahap in Supartha, 2004). The purpose of the assessment is to know and collect the information toward student progress and performances in order to achieve the objectives set out in the curriculum. The teacher answers on the interview, as follow:

"Students' learning achievement is still relatively mediocre, it means that most students are still dominated by students who can't absorb the lesson maximally so that the final results such as exam was less satisfactory and also still far from what teachers expect".

"Probably because of the factors in the school area so that students are less use of technology, whereas there are many that can be obtained from the internet for example to add insight from the learning model that teachers do. In other words that learning achievement is not always determined by the model of learning, depending on how effectiveness and creativity of the student in developing the lesson."

However, based on the results of the interview above, the researcher found that the teacher will continue to develop suitable learning models for students, and also, the teacher will constantly monitor to what extent the effectiveness of the learning models has been applied. And of course, there will be innovations to be applied in the assessment.

\section{CONCLUSION}

Based on the results of observation and interview of some respondents, the researcher concludes that there are some factors including motivation, learning model, classroom management, the use of facilities, and assessment which relate with teacher's performances in the classroom. From the observation, the researcher found that teacher always motivate his/her students to engage their interest in the learning process. Besides, he/she used cooperative learning model in his/her class. The teacher also try to maintain the classroom atmosphere in order the learning process can run properly and effectively. The teacher always try to create the best learning method which will best fit with students' needs. Further, students' perceptions toward teacher's performances in the classroom are positive. The students stated that teacher use such 
INTERACTION: Jurnal Pendidikan Bahasa; Vol. 7, No. 1; Mei 2020

ISSN: 2406-9558; E-ISSN: 2406-9566

interesting and attractive ways to teach them, like using game and English song, and also bring them to the public place like in the airport to learn English and practice English with foreigners. This activities will help students to learn English easily. Besides, it will easier the teacher to teach students if they are being active. But, it should keep in mind that every student is different, they have different personalities and characteristic, so it will not be the same. The teacher should find method that will best fit to all student's needs.

\section{REFERENCES}

Birjandi, P., \& Bagherkazemi, M. (2010). The Relationship between Iranian EFL Teachers' Critical Thinking Ability and Their Professional Success. English Language Teaching, 3 (2), 135-145.

Çakmak, M. (2009). The Perceptions of Student Teachers about the Effects of Class Size With Regard to Effective Teaching Process. The Qualitative Report, 14(3), 395-408. Retrieved from http://nsuworks.nova.edu/tqr/vol14/iss3/2.

Dalley-Trim, L. (2007). Students' Observations and Perceptions of Teacher "Performances" in the Classroom. Australian Journal of Teacher Education, 32(1). http://dx.doi.org/10.14221/ajte.2007v32n1.2.

Enock Alcine. (2019). Teachers' Perceptions of Academic Performance and Student Engagement Among Ninth-Grade Students. Walden University.

Halford, J. M. (1999). Easing the way for new teachers. In M. Scherer (Ed.), A better beginning: Supporting and mentoring new teachers (pp. 13-18). Alexandria, VA: Association for Supervision and Curriculum Development.

Hall, A. (2001). Professionalism and teacher ethics. In C. McGee, \& D. Fraser (Eds.), The professional practice of teaching (pp. 273-300). Palmerston North: Dunmore Press.

Hargreaves, A. (2003). Teaching in the knowledge society: Education in the age of insecurity. New York: Teachers College Press.

Hargreaves, A., \& Fullan, M. G. (1992). Understanding teacher development. New York: Teacher College Press.

Intan Kurniati. (2017). Student's Perception of their Teacher Teaching Style's. International Journal of sciences. 
INTERACTION: Jurnal Pendidikan Bahasa; Vol. 7, No. 1; Mei 2020

ISSN: 2406-9558; E-ISSN: 2406-9566

Mason, J. (1996). Qualitative researching. (London, Sage). Merriam, S. B. (1988). Case study research in education: A qualitative approach. (San Francisco, JosseyBass Publishers).

Mussawy, Sayed Ahmad Javid. (2009). "Assessment Practices: Student's and Teachers' Perceptions of Classroom Assessment". Master's Capstone Projects. 9. Retrieved fromhttps://scholarworks.umass.edu/cie_capstones/9.

Olorunfemi-Olabisi Florence Abiola. (2013). Students' Perception of Teachers' Factors in the Teaching and Learning of English Language in Nigerian Secondary Schools. Journal of Educational and Social Research, 3 (3). 